\title{
The Implementation of Adaptive Marketing Concept in the Educational Services Market
}

\author{
Olga Peskova, Tatiana Boriskina, Galina Mershieva, Elena Samsonova*, and Vera \\ Tsygankova
}

Volgograd State Technical University, 400005 Volgograd, Russia

\begin{abstract}
The sphere of higher education is in a state of transformation to new conditions of work, this requires the development of adaptive marketing strategies that make it possible to forecast development in an unstable environment. Trends in the Russian market for higher education services are dynamic and are currently associated with: an increase in the capacity of the Russian higher education market and sales of educational services, an increase in the mobility of participants in the educational services market, an increase in competition and the emergence of new participants offering innovative forms of educational services, an increase in demand for high-quality educational services and creative forms of their provision, compulsory attestations of state higher educational institutions, selection approach when recruiting the students. The article discusses the issues of building such a strategy based on the use of preventive response methods, proposes a sequence for implementing an adaptive marketing strategy, substantiates the procedure for conducting marketing research, as well as the possibility of using Internet technologies for positioning in the market.
\end{abstract}

\section{Introduction}

The current market situation in the provision of higher education services in Russia is characterized by high unpredictability and uncertainty due to the complex epidemiological situation, crisis foreign policy processes.

This problem is of interest not only to domestic researchers, but also to foreign researchers $[1.2,3]$, who were also pushed with this problem. The solution to this problem can be found both in social sciences (pedagogy, marketing, sociology, branding) and in technical (information technology, electronic educational systems, artificial intelligence).

We have used the concept of adaptive marketing, which allows us to assess the reaction of an educational organization to changes in both the internal and external environment, conduct a SWOT analysis, highlight target consumers, changes in their needs, teaching methods.

\footnotetext{
*Corresponding author: elesamsonova@yandex.ru
} 


\section{Methods and discussion}

In adaptive marketing, two main areas can be distinguished using economic and mathematical models and AMH (The adaptive market hypothesis) [4,5], as well as the

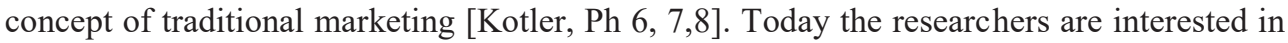
the possibilities of digitalization of education, adaptation to the changing requirements of the employer, the search for new markets, and the possible profitability of new sectors (mixed education).

An educational organization that quickly and flexibly responds to changes in the microand macroenvironment, quickly restructures its work to the changing conditions of functioning, takes into account promising opportunities and develops adequate ways to respond to emerging threats, is capable of retaining its place in the market, winning the competition, becoming a leader in the market. To write the article, we used the results of the authors' works $[9,10,11]$, describing the process of transformation of educational organizations.

The measures used by educational organizations in the field of higher education in the current period should be of a preventive nature, and the forecast should be based on data collected as a result of constant monitoring of the situation on the educational services market. (see Figure 1).

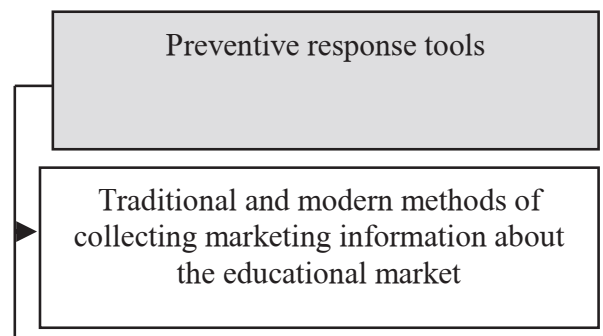

Methods for analyzing marketing information and forecasting trends in the development of the market situation in the educational services market

Marketing plans for the functioning of educational organizations, including flexible assortment, price, sales and communication policies

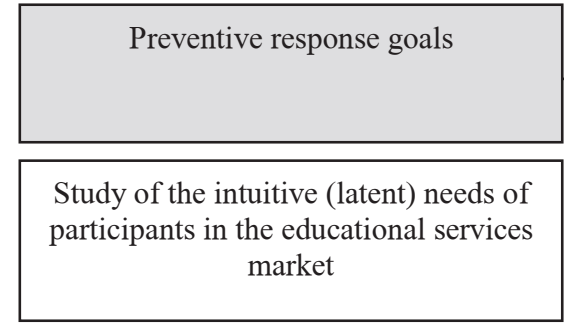

Forecasting events that satisfy the latent needs of participants in the educational services market

Development of recommendations for adapting an educational organization to the external environment and increasing its competitiveness in the educational services market

Fig. 1. Methods of preventive response of an educational organization to changes in the market situation (compiled by the authors) 


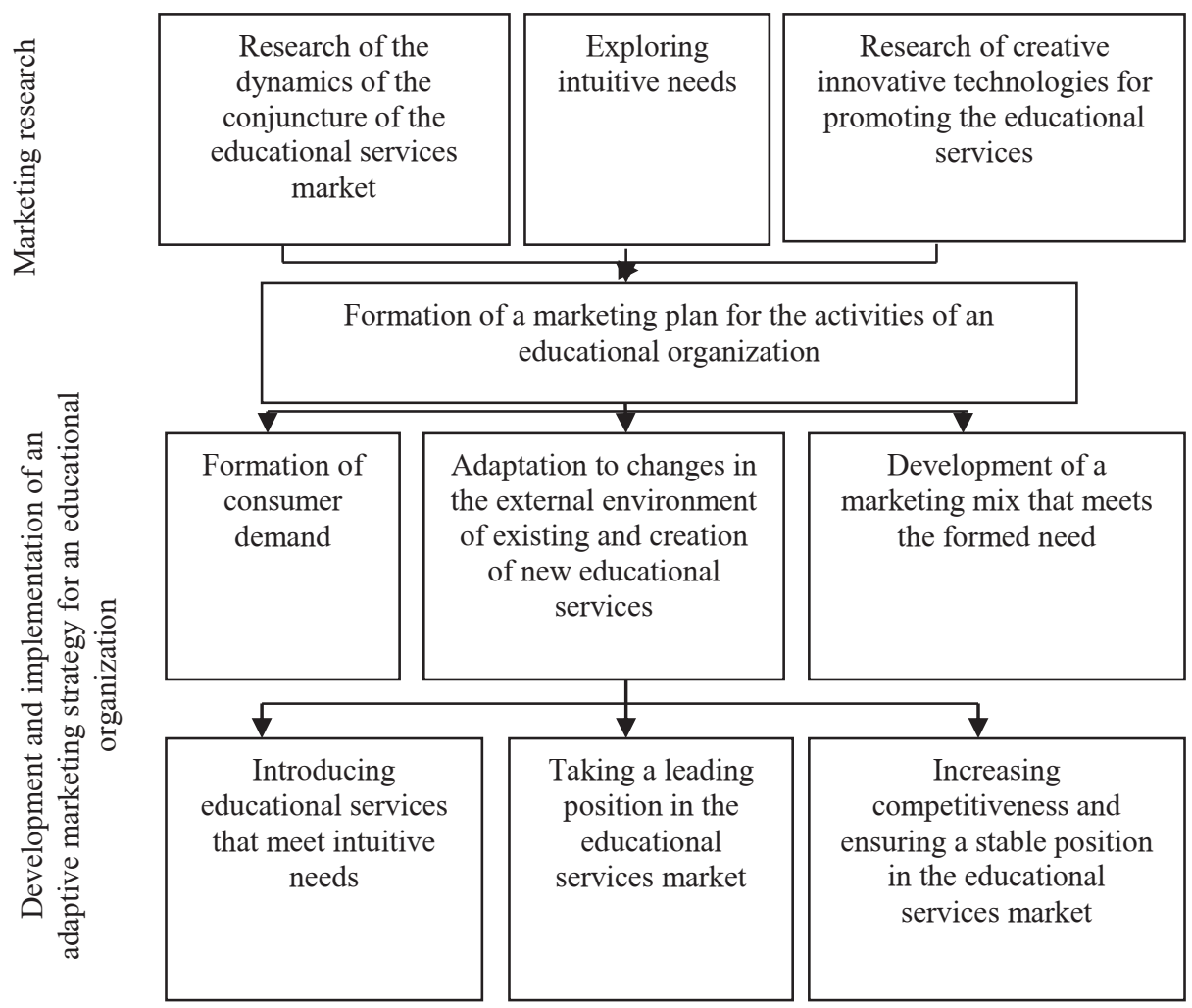

Fig. 2. The sequence of the implementation of the adaptive marketing strategy of the educational organization (compiled by the authors)

In this regard, in order to ensure sustainable existence in the market and increase the competitiveness of an educational organization, it is necessary to use the following sequence of actions when planning marketing activities. (see Figure 2).

The initial stage in the implementation of an adaptive marketing strategy is to conduct marketing research of the educational services market, the purpose of which is to study the emerging patterns of its development: (see Figure 3)

- quantity and quality of educational programs offered on the market of educational services, the demand for these educational programs, the dynamics of changes in the cost of educational services;

- intuitive needs of the main participants in the educational services market, which currently have no practical implementation in the form of educational programs;

- methods and technologies for promoting educational services existing on the market of educational services: studying the effectiveness of using traditional methods of promotion and modern ones associated with the active use of information technologies

The result of such a study should be a forecast for the development of an educational organization in the educational services market, in which it is necessary to assess the opportunities and threats of the market, strengths and weaknesses of the educational organization, competitors and their characteristics, target consumers of the educational organization. 


\begin{tabular}{|c|c|c|c|c|}
\hline \multicolumn{5}{|c|}{$\begin{array}{c}\text { Stage } 1 \text { - Defining the problem, research objectives - } \\
\text { Determination of the volume and quality of services, the study of intuitive needs }\end{array}$} \\
\hline \multicolumn{5}{|c|}{ Stage 2 - Determination of the research object and research objectives } \\
\hline \multicolumn{2}{|c|}{$\begin{array}{l}\text { Assessment of the dynamics of changes } \\
\text { in the conjuncture of the educational } \\
\text { services market, trends in its } \\
\text { development }\end{array}$} & \multicolumn{2}{|c|}{$\begin{array}{l}\text { Determination of the circle of } \\
\text { consumers, characteristics of their } \\
\text { behavior and motivation }\end{array}$} & $\begin{array}{l}\text { Internal and external } \\
\text { environment research }\end{array}$ \\
\hline \multicolumn{5}{|c|}{ Stage 3 - Development and implementation of the research plan } \\
\hline $\begin{array}{l}\text { Formation of a portrait of a } \\
\text { consumer of educational services } \\
\text { and determination of consumer } \\
\text { demand preferences }\end{array}$ & \multicolumn{2}{|c|}{$\begin{array}{l}\text { Formation of marketing tools to } \\
\text { influence consumer behavior in } \\
\text { the educational services market }\end{array}$} & \multicolumn{2}{|c|}{$\begin{array}{l}\text { Analysis and formation of } \\
\text { existing resources for the } \\
\text { implementation of activities } \\
\text { and marketing research } \\
\text { programs }\end{array}$} \\
\hline \multicolumn{5}{|c|}{$\begin{array}{c}\text { Stage } 4 \text { - Monitoring the implementation of marketing research and determining the effectiveness of the } \\
\text { implemented activities }\end{array}$} \\
\hline \multicolumn{5}{|c|}{$\begin{array}{l}\text { Stage 5 - Market development forecasts: } \\
\text { - opportunities and threats of the market, strengths and weaknesses of the educational institution; } \\
\text { - competitors and their features; } \\
\text { - target consumers; } \\
\text { - competitive advantages of educational services } \\
\text { - most effective means of communication with the environment of an educational organization }\end{array}$} \\
\hline
\end{tabular}

Fig. 3. The procedure for conducting marketing research on the educational services market (Source: compiled by the authors)

At the stage of developing and implementing an adaptive marketing strategy, it is necessary to form a need for an educational service that meets the intuitive needs of the target consumers of an educational organization [9].

Educational programs that satisfy latent needs must meet modern educational standards.

Educational organizations should have highly qualified employees capable of quick adaptation to environmental conditions, have a material and technical base equipped with all the resources necessary for the implementation of educational programs, including in a remote format.

The use of information technologies is important in the formation of demand and stimulating the sale of educational services that meet intuitive needs, which is especially important in the period of globalization and informatization of the population.

The epidemiological situation in the world and in the Russian Federation contributes to an increase in the effectiveness of the use of Internet technologies in the promotion of educational services:

- in conditions of a limited budget, they have advantages over traditional ones, since they are more affordable in cost;

- due to the significant limitation of interpersonal communications, the Internet environment becomes more attractive for finding the necessary information;

- Internet environment is more informative, the possibility of a unique and original presentation of information;

- has a higher efficiency in comparison with traditional means of promotion, greater coverage of the target audience.

The advantages of online promotion tools in the promotion of educational services are presented in Table 1.

Table 1. Internet technologies for promoting educational services when implementing an adaptive marketing strategy (Source: compiled by the authors)

\begin{tabular}{|l|l|}
\hline $\begin{array}{l}\text { Online promotion } \\
\text { tool }\end{array}$ & Features of application when implementing an adaptive marketing strategy \\
\hline $\begin{array}{l}\text { Contextual } \\
\text { advertising }\end{array}$ & $\begin{array}{l}\text { An advertising message about the activities of an educational organization should } \\
\text { appear in accordance with the content (content) of the page. }\end{array}$
\end{tabular}


Table 1. Continued

\begin{tabular}{|c|c|}
\hline $\begin{array}{l}\text { Display (banner) } \\
\text { ads }\end{array}$ & $\begin{array}{l}\text { It is aimed at forming a stable association of the name of the educational organization } \\
\text { with the services that it offers. }\end{array}$ \\
\hline $\begin{array}{l}\text { Newsletter by e- } \\
\text { mail }\end{array}$ & $\begin{array}{l}\text { Distribution by e-mail to partner organizations, educational organizations in which } \\
\text { future applicants study. }\end{array}$ \\
\hline \multirow{4}{*}{$\begin{array}{l}\text { Promotion of the } \\
\text { educational } \\
\text { organization's } \\
\text { website in social } \\
\text { media }\end{array}$} & $\begin{array}{l}\text { Social media optimization (SMO) is a set of technical measures aimed at transforming } \\
\text { the content of an educational organization's website in such a way that it can be used } \\
\text { as simply as possible in the online communities of an educational organization } \\
\text { (forums, blogs). }\end{array}$ \\
\hline & $\begin{array}{l}\text { Social media marketing (SMM) is the promotion of information about an educational } \\
\text { organization and educational services provided by it in social media (blogs, forums, } \\
\text { network communities). }\end{array}$ \\
\hline & $\begin{array}{l}\text { Social Ads uses information from the user's profile and places relevant ads for him } \\
\text { about the activities of educational organizations of interest to him. }\end{array}$ \\
\hline & $\begin{array}{l}\text { Optimization of the site of an educational organization: a convenient and friendly } \\
\text { interface based on the principle of openness, a convenient structure, a version of the } \\
\text { site in a foreign language - a complete analogue of the Russian version of the site, use } \\
\text { of a separate site for applicants, use of a separate site for an alumni association, } \\
\text { posting information on the site necessary for participation in educational organizations } \\
\text { in international rankings. }\end{array}$ \\
\hline SEO-optimization & $\begin{array}{l}\text { It is aimed at improving the position of issuing information about the website of an } \\
\text { educational organization in popular search engines. }\end{array}$ \\
\hline Viral marketing & $\begin{array}{l}\text { A memorable, massive transfer of interesting information, for example, by a well- } \\
\text { known graduate of an educational organization, which allows the consumer to get a } \\
\text { path to the educational service he needs with the subsequent transfer of this } \\
\text { information to his environment. }\end{array}$ \\
\hline $\begin{array}{l}\text { Online webinars, } \\
\text { seminars and } \\
\text { conferences }\end{array}$ & $\begin{array}{l}\text { Conducting one-way or two-way online meetings or presentations via the Internet in } \\
\text { real time in order to popularize the brand of an educational organization and inform } \\
\text { about the competitive advantages of its activities. }\end{array}$ \\
\hline $\begin{array}{l}\text { Creation and } \\
\text { development of } \\
\text { the internal } \\
\text { information } \\
\text { environment of an } \\
\text { educational } \\
\text { organization }\end{array}$ & $\begin{array}{l}\text { A channel of direct and feedback within the educational organization, aimed at deeper } \\
\text { and more effective communication between leaders, teachers, staff and students. }\end{array}$ \\
\hline
\end{tabular}

\section{Results}

The use of such a set of practical Internet marketing tools will allow an educational organization to bring information about their activities to a new level by:

- increasing traffic to the website of the educational organization;

- increasing the volume of sales and improving the efficiency of promoting the educational services, including new ones;

- improving the image of the educational organization;

- increasing brand awareness of the educational organization.

Comprehensive implementation of the activities described in the framework of the adaptive marketing strategy: conducting comprehensive marketing research using relevant methods for collecting and analyzing accurate and timely information about the activities of the organization, its environment, and the prospects for its development; development of marketing activities aimed at creating a need for high-quality, modern educational services that an educational organization can provide; constant monitoring and assessment of the effectiveness of an educational organization can increase the competitiveness of an educational organization, make its work more flexible and help strengthen its position in the market for higher education services. 


\section{References}

1. Ashley Berner, Educational Theory, 70, 105 (2020)

2. de P.G Barba., G.E Kennedy., M.D. Ainley, J. of Computer Assisted Learning, 32(3) ( 2016)

3. R. Deng, P. Benckendorff, D.Gannaway, Computers and Education, 129 (2019)

4. I.I. Topilina,Terra Economicus, 7(4-2), 317 (2009)

5. Andrew W. Lo, The Journal of Portfolio Management 30th Anniversary, 30(5) 15 (2004)

6. Ph. Kotler, M. Opresnik, K.Takaoka 21st Century Marketing: Digitalization and Transformation through Innovation, First Edition (2017)

7. R. Craig Lefebvre, Philip Kotler, Design Theory, Demarketing, and Behavioral Economics: Fostering Interdisciplinary Growth in Social Marketing, in Hastings and Bryants, The SAGE Handbook of Social Marketing (2012)

8. R. Achrol, Ph. Kotler, Journal of the Academy of Marketing Science, 40, 35 (2011)

9. E.V. Gugnin, E. V. Samsonova, M. V. Samsonova, Modern problems of science and education: electron. scientific. Journal, 2 (2015)

10. I. E. Belsky, T. B. Boriskina, E. V. Samsonova, G. A. Mershieva, V. N. Tsygankova, Economics and entrepreneurship, 7(96) (2018)

11. M. V. Samsonova, E. V. Samsonova, G. A. Mershieva, The Bulletin of Adyghe State University. Economy Series, 3(205), 110 (2017)

12. M. Platis, G. Baban, Annals of the University of Oradea : Economic Science, 1 (2010)

13. $13 \mathrm{Ph}$. Kotler, D. Jain, S. Maesincee Nine Major Shifts in the New Economy Electronic Customer Relationship Management, 15 (2001) 